\title{
Notica o mednarodni konferenci EUROPHRAS 2008
}

\author{
Nataša Jakop
}

IZVLEČEK: V prispevku avtorica poroča o mednarodni konferenci EUROPHRAS 2008, ki je bila od 13. do 16. avgusta 2008 v Helsinkih na Finskem. Konference z naslovom »Frazeologija globalno-arealno - regionalno« se je udeležilo približno 200 udeležencev iz evropskih in drugih držav, med njimi tudi šest iz Slovenije.

\begin{abstract}
Note on the EUROPHRAS 2008 International Conference ABSTRACT: This paper reports on the EUROPHRAS 2008 international conference, held from 13 to 16 August 2008 in Helsinki, Finland. The conference, titled "Phraseology: Global-Areal-Regional," was attended by approximately 200 participants from Europe and beyond, including six from Slovenia.
\end{abstract}

Sredi avgusta, tj. od 13. do 16., je v Helsinkih na Finskem potekala frazeološka konferenca, ki jo kot del svojega programa redno organizira Evropsko združenje za frazeologijo. Tokrat je bil soorganizator konference Inštitut za germanistiko Univerze v Helsinkih, predsednik organizacijskega odbora pa ugledni finski frazeolog, prof. dr. Jarmo Korhonen, avtor osmih monografij in več kot šestdesetih znanstvenih in strokovnih prispevkov.

Konference z naslovom »Frazeologija globalno - arealno - regionalno« se je udeležilo približno 200 udeležencev iz evropskih in drugih držav, tj. Avstrije, Belgije, Bosne in Hercegovine, Češke, Danske, Estonije, Finske, Francije, Hrvaške, Irske, Islandije, Italije, Japonske, Kanade, Latvije, Madžarske, Makedonije, Nemčije, Nigerije, Nizozemske, Nove Zelandije, Poljske, Portugalske, Romunije, Rusije, Slovaške, Slovenije, Španije, Švedske, Švice, Tunizije, Turčije, Ukrajine in ZDA, da bi poglobljeno razmislili o tem, kako se frazeologija v različnih jezikih in kulturah danes odziva na močne in neizbežne vplive globalizacije (http://www.helsinki.fi/ hum/sala/europhras/).

V središču dogajanja prvega in drugega dneva konference so bili plenarni govori: predavanje nemške frazeologinje Elisabeth Piirainen o iskanju skupnih lastnosti v frazeologiji evropskih jezikov s kulturološkega vidika, Wolfganga Miederja z vermontske univerze o prevajanju in distribuciji angloameriških pregovorov v Evropi, Wolfganga Eismanna z univerze v Gradcu o prisotnosti ruskih frazemov v evropskih jezikih, Antonia Pamiesa z univerze v Granadi o razmerju med nacionalnimi 
posebnostmi v jeziku in kulturi ter jezikovno globalizacijo. Drugi dan smo lahko slišali še tri predavanja: Harald Burger in Peter Zürrer z univerze v Zürichu sta razpravljala o francoskih in italijanskih vplivih na nemško frazeologijo, madžarski frazeolog Csaba Földes o vplivih nemškega jezika na nekatere slovanske frazeološke sisteme, Kari Keinästö z univerze v Turku o prisotnosti frazemov nemškega izvora na severu Evrope. Takoj zatem so sledili številni dvajsetminutni referati, porazdeljeni v sedem vzporednih sekcij. Organizatorji konference so napovedali, da bo vsebina referatov $\mathrm{v}$ prihodnjem letu objavljena $\mathrm{v}$ zborniku. Zaenkrat lahko rečemo, da je bilo ponujenega veliko raznovrstnega frazeološkega gradiva, obravnavanega zlasti kontrastivno in z namenom poiskati različna medjezikovna in medkulturna prepletanja, vsi referenti pa so sodelovali tudi v bolj ali manj živahni desetminutni diskusijski razpravi. Vzporedno je potekala še projektna delavnica »Kolokacije v specializiranih diskurzih«, vsebinsko povezana z mednarodnim raziskovalnim projektom »Razširjenost idiomov v Evropi in širše«, ki ga vodi prof. dr. Elisabeth Piirainen in katerega cilj je raziskati skupne jedrne sestavine vseh tistih idiomov, ki soobstajajo v evropskih, pa tudi drugih jezikih. V tem projektu sodeluje že okrog 190 raziskovalcev $\mathrm{z}$ vsega sveta.

Pomenljiv je sorazmerno velik delež slovenske frazeologije na konferenci, saj je na njej s štirimi prispevki sodelovalo šest slovenskih raziskovalcev z ljubljanske, mariborske in koprske univerze ter $z$ Inštituta za slovenski jezik Frana Ramovša ZRC SAZU (Erika Kržišnik, Urška Valenčič Arh, Vida Jesenšek, Mateja Jemec Tomazin, Polona Gantar in Nataša Jakop).

Popolnoma zapolnjeni vsebinski del programa sta razbremenila topla sprejema v mestni hiši in na univerzi, konferenco pa je v megli in dežju sklenil izlet na Suomenlinno (Sveaborg), vojaško utrdbo iz 18. stoletja, ki je danes pod Unescovo zaščito in med Helsinčani priljubljeno prizorišče piknikov in sprostitve.

Za raziskovalce, navdušene nad frazeologijo, velja omeniti še to, da bo naslednje veliko srečanje evropskih frazeologov leta 2010 v Granadi, in še več, na občnem zboru društva je bil sprejet predlog, da bi se konferenca Evropskega združenja za frazeologijo leta 2012 odvijala v Mariboru. 